Sargent, F., II, Sargent, V. W., Johnson, R. E. \& Stolpe, S. G. (1955). The Physiological Basis for $V$ arious Constituents in Survival Rations. II. The Efficiency of Young Men under Conditions of Moderate Cold. Vol. I and II. Ohio: WADC Technical Report 53-484, Wright-Patterson Air Force Base.

Shaffer, P. A. (1921). F. biol. Chem. 47, 449.

\title{
Physiological reactions of cattle to climatic stress
}

\section{By J. D. Findlay, Hannah Dairy Research Institute, Kirkhill, Ayr}

All the available evidence indicates that cattle are highly resistant to cold, and that temperatures as low as $-18^{\circ}$ have very little effect on their physiological reactions, although in cold conditions food consumption and heat production increase. High environmental temperatures or heat stress, however occasioned, have marked effects on the grazing behaviour, food and water consumption, milk production, milk and blood composition, cardio-respiratory behaviour, heat production and body temperature of cattle. This brief review is, therefore, largely concerned with the effects of heat stress on cattle.

The basis of work on the environmental physiology of cattle, and its ultimate purpose, is the improvement of cattle productivity in hot countries and the definition of environmental conditions for optimum productivity in cattle shelters in this country. Many studies (Brody, I948; Findlay, 1950, 1954; Wright, 1954) have shown that there are profound differences in the ability to withstand thermal stress, i.e. in the heat tolerance, of tropical and European breeds of cattle, of different breeds of European cattle and of individuals of any one pure breed. These differences may be based on the anatomy, the nutrition, the heat production or the heat-loss mechanisms of the cattle concerned or on a combination of any or all of these properties.

The most carefully controlled work on the subject has been performed in climatic rooms in which the air temperature and humidity can be varied throughout wide ranges with very fine limits of control. Such work has been largely concerned with elucidating the gross reactions to severe thermal stress of the intact animal and the nature of temperature regulation in cattle. Very little work has been done on the nutritional aspects of bovine physiology with reference to climatic stress but certain important connexions between nutrition and climatic stress can be discerned in the published literature.

The most immediate reaction of cattle to heat stress is to limit their food intake, and this limitation is shown in their grazing behaviour under hot conditions. European breeds virtually cease grazing and seek the shade at air temperatures around $28^{\circ}$ or when their body temperatures reach about $39^{\circ} I^{\circ}$. It was shown, for example, by Seath \& Millar (1946) that Jersey and Holstein cows spent only I I\% of their time grazing on hot sunny days when the shade temperature was $30^{\circ}$, whereas at night when the shade temperature was $27^{\circ}$ they spent $37 \%$ of their time grazing. This observation illustrates the added heat burden of solar radiation and emphasizes the need for providing good pasture at night for animals that have to withstand a 
high degree of insolation. In this connexion Payne, Laing \& Raivoka (I95I) observed the grazing habits of Friesian cows in Fiji and noted that they grazed mainly at night $(67 \%$ of the total grazing time) and that only some $19 \%$ of the nocturnal period was spent lying down, whereas during the day the cows lay down, i.e. did not graze for some $66 \%$ of the total time.

The reduction in food intake with heat stress shown by such field work has been studied in detail in climatic rooms, notably by Brody and his associates in the U.S.A. This work, summarized by Cobble \& Herman (195I) and by Worstell \& Brody (1953), has shown that increasing the air temperature above $27^{\circ}$ caused a rapid depression in food consumption in European breeds of cattle which ceased to feed at an air temperature of $4 \mathrm{x}^{\circ}$.

As the food consumption decreases with increasing temperature the water consumption increases, with large individual variations in the quantity drunk and in the frequency of drinking (Thompson, Worstell \& Brody, r949; Ragsdale, Thompson, Worstell \& Brody, I950). In general, the higher water consumption reduces the progressive increments in body temperature that occur with increasing stress so that there is less depression of milk yield and food consumption. With increasing water consumption greater volumes of more dilute urine are excreted. Refrigerated drinking water, as Ittner, Kelly \& Guilbert (195I) have demonstrated, increases live-weight gains in the tropics by its direct cooling effect on cattle.

As a result of the decrease in food consumption the productivity of the animal is adversely affected. Milk yield declines in European breeds when the temperature exceeds about $27^{\circ}$ but is virtually unaffected in tropical breeds (Cobble \& Herman, 195 I). In many cattle there is a greater decline in food consumption than in milk production, which leads to loss in body-weight. This loss, hor. zver, is less than it might be, owing partly to replacement of body fat by water and partly to a parallel decrease in heat production (Worstell \& Brody, 1953).

These changes are associated with changes in the composition of the milk. The levels of total solids and chloride increase and those of lactose, total nitrogen and total solids-not-fat decrease in the milk of European cattle subjected to temperatures in excess of $27^{\circ}$. Blood composition is also affected owing to changes in the food intake. Blood creatinine increases with increasing rectal temperature, probably as a result of the accelerated endogenous nitrogen katabolism following the decline in food consumption (Worstell \& Brody, I953). In contrast to man, cattle subjected to thermal stress do not exhibit disturbances in their water or electrolyte balance or in the protein concentration in the blood. Short exposures of calves to very severe heat stress produce transient haemoconcentration but it is due more to mobilization of erythrocytes than to loss of water from the blood. During short exposures blood and plasma volumes tend to increase (Bianca, I957).

The absence of changes in the electrolyte balance of the blood of cattle exposed to heat stress is directly related to the profound differences between cattle and man in their cardio-respiratory behaviour and skin function. Cattle increase their frequency of respiration and ventilation and hence their vaporization of moisture when exposed to high environmental temperatures. European cattle exhibit a sudden 
acceleration in outer surface vaporization at an air temperature of around $16^{\circ}$. This acceleration declines as an air temperature of $24^{\circ}$ is exceeded, with a consequent rise in rectal temperature to the near-lethal level of $42^{\circ}$ at an air temperature of $41^{\circ}$. This behaviour is in marked contrast to what happens in man, whose cooling by outer surface vaporization enables a normal rectal temperature to be maintained in similar circumstances. In cattle at $4 \mathrm{I}^{\circ}$ environmental temperature the ratio of evaporative heat loss to heat production is roughly half that of the corresponding ratio for man (Worstell \& Brody, I953).

The low sweating capacity of cattle under heat stress is shown also by the behaviour of their skin temperature. Their surface temperature becomes identical with environmental temperature at $4 \mathrm{I}^{\circ}$ when the rectal temperature is $42^{\circ}$ (Worstell \& Brody, I953). In the calf the skin temperature varies linearly with air temperature in the range $20^{\circ}-40^{\circ}$ (Beakley \& Findlay, $1954^{-5}$ ). Vasodilatation is almost maximal in the calf at $20^{\circ}$ air temperature (Beakley \& Findlay, $1954-5^{b}$ ), and the heart rate increases only slightly with increasing heat stress in contrast to what is observed under similar circumstances in man (Beakley \& Findlay, I954-5c).

Although, compared with man, cattle are poorly-sweating mammals they nevertheless possess sweat glands, one to each hair follicle in a density about ten times that possessed by man. These sweat glands are apocrine and have a poor blood supply (Findlay \& Yang, 1950). Their secretion consists largely of a mucopolysaccharide (Yang, 1952; Nisbet, 1956), and it has been shown by Freeborn, Regan $\&$ Berry (I 934) that chloride is not secreted by the glands. Like the sweat glands of the horse those of cattle respond to injection of adrenaline and are not cholinergic (Ferguson \& Dowling, 1955; Taneja, 1956). Losses of potassium, sodium and chloride by the dermal route are therefore likely to be of little significance in cattle subjected to thermal stress.

Very generally, the phenomenon of panting in cattle is qualitatively the equivalent of profuse sweating in man. Thermal polypnoea in cattle is initiated by peripheral thermal stimulation without rise in deep-body temperature (Bligh, I957a) and the frequency can attain exceedingly high levels from a normal of about 25 to as much as 250 respirations/min. The rate of ventilation increases almost linearly with increasing environmental temperature. The rate of increase of ventilation is maintained initially by increasing the frequency and diminishing the tidal volume until at an upper critical rectal temperature of $40^{\circ} 5^{\circ}$, when the frequency is maximal, tidal volume increases and the frequency is consequently reduced (Findlay, 1957). Overventilation occurs during this last phase, reaching levels of $901 . / \mathrm{min}$ in the calf, and the heart rate is dramatically increased (Bianca, 1958). Although all evaporative and convective cooling occurs in the upper respiratory tract and not in the lungs (Bligh, 1957b) the high rate of ventilation eventually results in respiratory alkalosis (Dale \& Brody, 1952; Bianca, 1954-5). During thermal polypnoea in cattle copious drooling of saliva and mucus occurs. The saliva thus secreted may amount to $18 \mathrm{l}$./ day in cattle of European breeds and is equivalent to a daily loss of $50-80 \mathrm{~g}$ minerals (Bonsma, I948). This drain on the animal's mineral reserves could have a marked effect on its constitution, and it is possible that the effects of many so-called mineral 
deficiencies of soil in the tropics are in part due to mineral wastage by excess salivation. Tropical cattle under similar environmental conditions salivate only slightly and do not markedly increase their respiratory frequency.

The marked resistance of European breeds of cattle to cold, referred to at the beginning of this review, is due to conservation of heat by reduction of respiratory frequency, to the growth of a denser coat in cold seasons, to pilomotor activity increasing the insulation of the coat, to the specialized arrangement of venae comites in the vascular supply to the skin (Goodall \& Yang, 1954), to the presence of numerous arterio-venous anastomoses in the appendages (Goodall, 1955) and to the higher metabolic rate and overall heat production per unit surface area of cattle compared with man.

The relative inefficiency of heat disposal in cattle is shown in the behaviour of the rectal temperature, which begins to rise under quite moderate conditions of thermal stress. The magnitude of the rise in rectal temperature or its rate of rise under various conditions of thermal stress has therefore formed the basis of measurement of the heat tolerance of cattle. The most widely used heat-tolerance test is that of Rhoad (r944) who defined a heat-tolerance coefficient (H.T.C.) as:

$$
\text { H.T.C. }=100-10\left(T_{R}-101\right),
$$

where $T_{R}$ is the rectal temperature in ${ }^{\circ} \mathrm{F}$. after the animal has been exposed to a certain heat stress and Ior is the so-called normal rectal temperature of cattle expressed in ${ }^{\circ} \mathrm{F}$. The applications of this test in field studies have been reviewed in detail by Findlay (1950). Using Rhoad's test, Yeates (1956) has recently shown that good condition in cattle is not in itself a disadvantage in withstanding heat but, as might be expected, a high rate of feeding in cattle in either good or poor condition under heat stress adds seriously to the heat burden. When undernourished animals were given liberal rations their heat tolerance was still high 2 days after the change and it did not diminish until the 6th day. Yeates ascribes this lag to what he calls conditioning of the digestive tract to better feeding after deprivation. Control over the feeding routines of cattle subjected to Rhoad's test has made interpretation of the published work very difficult. Other methods of defining heat tolerance have been described by Beakley $\&$ Findlay (1954-5d) for European-type calves.

The effects of parameters of climate other than temperature, such as radiation, humidity and wind velocity have been studied, though somewhat cursorily, by Brody and his colleagues (Brody, Ragsdale, Thompson \& Worstell, 1954a,b; Kibler \& Brody, 1953, I954a,b; Ragsdale, Thompson, Worstell \& Brody, I953; Thompson, Worstell \& Brody, I953; Stewart \& Brody, 1954; Thompson, Yeck, Worstell \& Brody, 1954). No particular physiological reactions can be ascribed to any of these parameters that are not due simply to an increase in the heat burden by increase in the environmental heat gain (radiation), reduction of outer-surface vaporization (humidity) or reduction in convective heat loss (wind speed).

In summary, it will be apparent that the nutritional aspects of climatic stress on cattle are most closely connected with the reduction of food intake which occurs under heat stress. The differences between cattle and man in their physiological 
reactions to heat have been stressed, particularly with reference to vasomotor control level, cardio-respiratory behaviour and skin function. These differences emphasize the danger of applying to cattle in a facile way knowledge derived from studies of heat stress on man. The paucity of knowledge concerning the nutrition of cattle under heat stress is only too apparent, but is not surprising in view of the complexity not only of the climatic factors involved but of the instruments and facilities required for their study.

\section{REFERENCES}

Beakley, W. R. \& Findlay, J. D. (1954-5a). भ. agric. Sci. 45, 353 .

Beakley, W. R. \& Findlay, J. D. (1954-5b). 7. agric. Sci. 45, 373.

Beakley, W. R. \& Findlay, J. D. (1954-5c). F. agric. Sci. 45, 461.

Beakley, W. R. \& Findlay, J. D. (1954-5d). F. agric. Sci. 45, 339.

Bianca, W. (1954-5). F. agric. Sci. 45, 428.

Bianca, W. (1957). Brit. vet. F. 113, 227.

Bianca, W. (1958). F. agric. Sci. (In the Press.)

Bligh, J. (1957a). F. Physiol. 136, 413.

Bligh, J. (1957b). F. Physiol. 136, 404.

Bonsma, J. C. (1948). Fmg in S. Afr. 15, 373.

Brody, S. (1948). Res. Bull. Mo. agric. Exp. Sta. no. 423.

Brody, S., Ragsdale, A. C., Thompson, H. J. \& Worstell, D. M. (1954a). Res. Bull. Mo. agric. Exp. Sta. no. $55^{6}$.

Brody, S., Ragsdale, A. C., Thompson, H. J. \& Worstell, D. M. (1954b). Res. Bull. Mo. agric. Exp. Sta. no. 545 .

Cobble, J. W. \& Herman, H. A. (195I). Res. Bull. Mo. agric, Exp. Sta. no. $4^{85}$.

Dale, H. E. \& Brody, S. (1952). F. Anim. Sci. 1x, 790.

Ferguson, K. A. \& Dowling, D. F. (1955). Aust. F. agric. Res. 6, 640.

Findlay, J. D. (1950). Bull. Hannah Dairy Inst. no. 9.

Findlay, J. D. (1954). Met. Monogr. 2, 19.

Findlay, J. D. (1957). F. Physiol. 136, 300 .

Findlay, J. D. \& Yang, S. H. (1950). F. agric. Sci. 40, 125.

Freeborn, S. B., Regan, W. M. \& Berry, L. J. (1934). F. econ. Ent. 27, $3^{82}$.

Goodall, A. M. (1955). F. Anat., Lond., 87, 66 .

Goodall, A. M. \& Yang, S. H. (1954). F. agric. Sci. 44, I.

Ittner, N. R., Kelly, C. F. \& Guilbert, H. R. (195r). F. Anim. Sci. ro, 742.

Kibler, H. H. \& Brody, S. (I953). Res. Bull. Mo. agric. Exp. Sta. no. 522.

Kibler, H. H. \& Brody, S. (I954a). Res. Bull. Mo. agric. Exp. Sta. no. 552.

Kibler, H. H. \& Brody, S. (1954b). Res. Bull. Mo. agric. Exp. Sta. no. 574.

Nisbet, A. M. (1956). Studies in the histology of bovine skin. Thesis, University of Glasgow.

Payne, W. J. A., Laing, W. I. \& Raivoka, E. N. (I95 I). Nature, Lond., 167, 610.

Ragsdale, A. C., Thompson, H. J., Worstell, D. M. \& Brody, S. (1950). Res. Bull. Mo. agric. Exp. Sta. no. 460 .

Ragsdale, A. C., Thompson, H. J., Worstell, D. M. \& Brody, S. (1953). Res. Bull. Mo. agric. Exp. Sta. no. 521 .

Rhoad, A. O. (1944). Trop. Agriculture, Trin., 21, 162.

Seath, D. M. \& Miller, G. D. (I946). F. Dairy Sci. 29, 199.

Stewart, R. E. \& Brody, S. (1954). Res. Bull. Mo. agric. Exp. Sta. no. 56r.

Taneja, G. C. (1956). Nature, Lond., 177, 482 .

Thompson, H. J., Worstell, D. M. \& Brody, S. (1949). Res. Bull. Mo. agric. Exp. Sta. no. 436.

Thompson, H. J., Worstell, D. M. \& Brody, S. (1953). Res. Bull. Mo. agric. Exp. Sta. no. 53 I.

Thompson, H. J., Yeck, R. G., Worstell, D. M. \& Brody, S. (1954). Res. Bull. Mo. agric. Exp. Sta. no. 548 .

Worstell, D. M. \& Brody, S. (1953). Res. Bull. Mo. agric. Exp. Sta. no. 5 I 5.

Wright, N. C. (1954). In Progress in the Physiology of Farm Animals. Vol. I, p. 191. [J. Hammond, editor.] London: Butterworths Scientific Publications.

Yang, S. H. (1952). J. agric. Sci. 42, 465 .

Yeates, N. T. M. (1956). Nature, Lond., 178, 702. 